\title{
NiAl INTERMETALLIC PREPARED WITH REACTIVE SINTERING AND SUBSEQUENT POWDER-METALLURGICAL PLASMA-SINTERING COMPACTION
}

\author{
REAKCIJSKO SINTRANJE IN ZGOŠČEVANJE S PLAZEMSKIM \\ SINTRANJEM NiAl INTERMETALNE ZLITINE
}

\author{
Alena Michalcová ${ }^{1}$, Dalibor Vojtěch ${ }^{1}$, Tomáš František Kubatík ${ }^{2}$, Pavel Novák ${ }^{1}$, \\ Petr Dvořák ${ }^{1}$, Petra Svobodová ${ }^{1}$, Ivo Marek ${ }^{1}$ \\ ${ }^{1}$ University of Chemistry and Technology, Department of Metals and Corrosion Engineering, Prague, Technická 5, 16628 Prague 6, \\ Czech Republic \\ ${ }^{2}$ Institute of Plasma Physics AS CR, v. v. i., Za Slovankou 1782/3, 18200 Prague 8, Czech Republic \\ michalca@vscht.cz \\ Prejem rokopisa - received: 2015-04-30; sprejem za objavo - accepted for publication: 2015-06-02
}

doi:10.17222/mit.2015.089

This paper proposes a novel method for powder-metallurgy preparation of compact NiAl intermetallics. In the first step, the $\mathrm{NiAl}$ powder is prepared with the reactive-sintering procedure. The porous NiAl product of the SHS reaction is milled to a fine powder and consequently compacted by SPS processing. The compaction of powder metals and alloys is a very difficult field due to the need of preserving the unique properties of the initial materials. One of the few possible methods of a successful compaction is plasma sintering. To describe detailed structures of powder-metallurgy materials, it is necessary to use advanced microscopy methods such as SEM and TEM. In this study, the structure of a NiAl intermetallic compound is described. The material was first produced, with reactive sintering, from pure elements. Subsequently, the NiAl porous master alloy was milled and compacted with the spark-plasma-sintering (SPS) technique. The particle size of the NiAl powder was comparable to the grain size of the compacted material, which exhibited a low porosity. It was proved that the interconnection of the NiAl particles is made by a thin layer of nanocrystalline oxides.

Keywords: SPS, intermetallics, powder metallurgy

Članek predlaga novo metodo za pripravo kompaktne NiAl intermetalne zlitine s pomočjo metalurgije prahov. V prvem koraku je bil NiAl prah pripravljen s postopkom reakcijskega sintranja. Z SHS reakcijo proizvedeni porozni NiAl je bil zmlet v droben prah in nato kompaktiran z SPS postopkom. Kompaktiranje kovinskega prahu je težavno zaradi potrebe po zadržanju enkratnih lastnosti začetnih materialov. Ena od redkih uspešnih metod kompaktiranja je sintranje s plazmo. Za podroben opis mikrostrukture materialov v metalurgiji prahov je potrebno uporabiti napredne mikroskopske metode, kot sta SEM in TEM. V študiji je opisana struktura intermetalne zlitine NiAl. Material je bil najprej izdelan z reakcijskim sintranjem iz čistih elementov. Nato je bila porozna zlitina NiAl zmleta in kompaktirana s tehniko iskrilnega plazma sintranja (SPS). Velikost delcev prahu NiAl je bila primerljiva z velikostjo zrn v kompaktiranem materialu, ki je imel tudi majhno poroznost. Dokazano je bilo, da se povezava delcev NiAl izvede s tanko plastjo nanokristaliničnih oksidov.

Ključne besede: SPS, intermetalne zlitine, metalurgija prahov

\section{INTRODUCTION}

Like many other transition metal aluminides, nickel aluminide exhibits properties that are very interesting for industrial utilization. These are a high melting point $\left(1638{ }^{\circ} \mathrm{C}\right)$, a low density $\left(5.95 \mathrm{~g} / \mathrm{cm}^{3}\right)$, a high thermal conductivity ( $70 \mathrm{~W} \mathrm{~m}^{-1} \mathrm{~K}^{-1}$ ), an excellent corrosion resistence $^{1,2}$ and a very good wear resistance. ${ }^{3}$ These properties allow intermetallics to be used in the applications where metallic and ceramic materials fail. In addition, nickel aluminide is easily produced in atmospheric air with a self-propagating high-temperature synthesis (SHS) ${ }^{2,4-5}$ even when pre-pressed into a green body. ${ }^{4}$ This makes the Ni-Al system to be an ideal model for the study of a possible powder preparation using metallurgical methods based on SHS.

The intermetallic materials usually exhibit good mechanical properties at elevated temperatures, but unfortunately, they seem to be quite brittle at room temperature. When decreasing the grain size of a material, this factor limiting its utilization can be solved. One of the promising ways is to produce fine-grained intermetallics with a two-step powder-metallurgy method: in the first step, an intermetallic is formed with the SHS procedure; then it is milled to a very fine powder and compacted with the spark-plasma-sintering (SPS) procedure. The advantage of the SPS process lies in extremely short sintering times, due to which there is almost no grain coarsening. ${ }^{6-9}$ The SPS method is well described for ceramics, but for metals and especially for intermetallics, the description of the process is still being formed. ${ }^{6-9}$

The spark-plasma sintering method has been very popular in the last two decades, mainly in the field of compaction of ceramics. It is an ideal tool for obtaining homogenous nanocrystalline bulk materials with a high density, i.e., fine-grained ceramics, thermo-electric semi- 
conductors and biomaterials. ${ }^{6}$ Compared to the other compaction methods (cold and hot isostatic pressing), the SPS is distinguished by a low overall sintering temperature, short sintering times and better properties of the prepared bulk materials. ${ }^{7}$

Using the SPS method, many successes were achieved in the fields of increasing the superplasticity of ceramic materials, improvement of magnetic properties, reduction of the amount of impurities segregated at the grain boundaries, improvement in the binding quality and many others. ${ }^{7}$ From the historical point of view, the first machine comparable to SPS was built in Germany, as reported in reference ${ }^{6}$. In 1933, in the USA, F. Taylor was awarded a patent for the first resistance-sintering method used for sheets. ${ }^{10}$

Basically, the SPS method for sintering materials can be divided into four generations: the first SPS was built in Japan (in 1962) and called spark sintering (SS). ${ }^{11}$ The next generation can be described as plasma-activated sintering (PAS), followed by spark-plasma sintering (SPS), while the fourth and currently the last generation is the one described in ${ }^{12}$.

The study of a NiAl alloy prepared with SPS can be used, in future, as a milestone for the preparation of NiAl-based composites. ${ }^{2}$ Preparation conditions can be easily changed by adding reinforcements to the reaction system before the SHS reaction or by adding them to the powder before the SPS compaction.

\section{EXPERIMENTAL WORK}

The NiAl intermetallic compound was prepared with an SHS synthesis. A high-purity nickel powder with a particle size $<100 \mu \mathrm{m}$ and an aluminium powder with a purity of $99.99 \%$ and a particle size of 200-400 $\mu \mathrm{m}$ were mixed and pressed at room temperature with a pressure of $260 \mathrm{MPa}$ using a LabTest 5.250SP1-VM universal testing machine. Reactive sintering of the pressed powder mixtures was carried out at $900{ }^{\circ} \mathrm{C}$ for

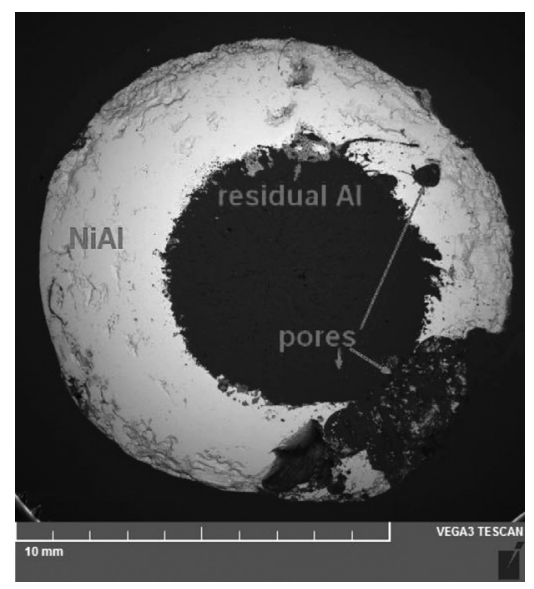

Figure 1: Structure of a NiAl particle prepared with SHS procedure (SEM/BSE)

Slika 1: Struktura delca NiAl, izdelanega z SHS postopkom (SEM/BSE)
$15 \mathrm{~min}$ in the usual furnace (air) atmosphere. The sintered particles with an approximately cylindrical shape and a size of $1 \mathrm{~cm}$ in diameter and $1 \mathrm{~cm}$ in height were milled with a laboratory vibration mill VM4. The obtained NiAl powder was leached in a $20 \% \mathrm{NaOH}$ solution to dilute any residual $\mathrm{Al}$. The NiAl powder was compacted with the SPS procedure (model SPS 10-4 thermal technology) at a temperature of $1100{ }^{\circ} \mathrm{C}$, for a compaction-process time of $5 \mathrm{~min}$ and at a pressure of 80 MPa. The SPS die is made of carbon and its internal diameter is $19.3 \mathrm{~mm}$. To separate the sintered material from the die, a carbon foil with a thickness of $0.15 \mathrm{~mm}$ was used. The amount of compacted material was approximately $5 \mathrm{~g}$ for each experiment.

The structures of the SHS material, the NiAl powder and the SPS-compacted material were observed with an Olympus PME3 light microscope and a TESCAN VEGA 3 LMU scanning electron microscope equipped with EDS and EBSD detectors (Oxford Instruments). The phase compositions of the materials were determined using X-ray diffraction (PAN analytical X'Pert PRO + High Score Plus, $\mathrm{Cu}$ anode). TEM samples were prepared by ion polishing using Gatan PIPS Model 691 and consequently observed with a Jeol JEM 3010 transmission electron microscope. SAED patterns were integrated and phases were identified using Process Diffraction software. The hardness of the materials was measured with a FUTURE-TECH FM700 hardness tester with loads of $10 \mathrm{~g}$ and $1 \mathrm{~kg}$.

\section{RESULTS AND DISCUSSION}

The samples prepared with the SHS procedure had approximately cylindrical shapes. They were mainly composed of the NiAl phase with a low amount of residual $\mathrm{Al}$ in the surroundings of the pores. As illustrated in Figure 1, the porosity of the SHS samples is extremely high.

The NiAl particles were milled into a powder, whose structure is shown in Figure 2. The particles have irregular shapes, as expected after milling a brittle material.

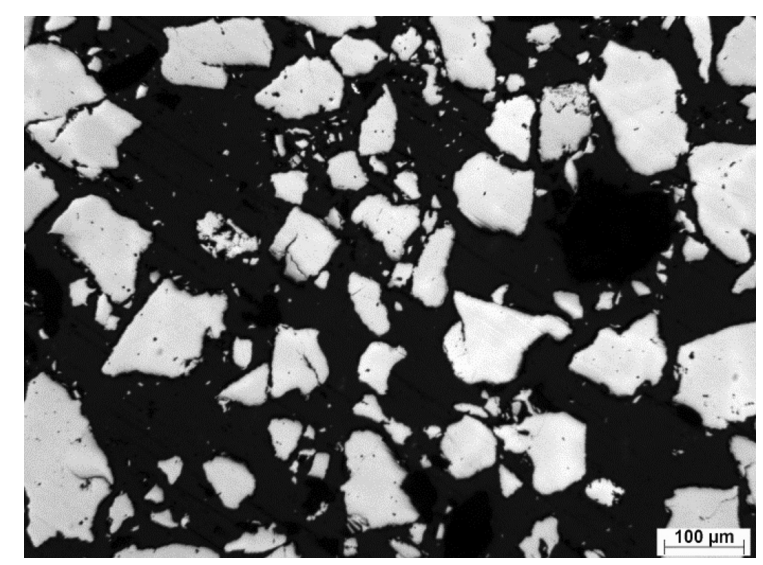

Figure 2: Structure of NiAl powder (LM) Slika 2: Struktura NiAl prahu (LM) 


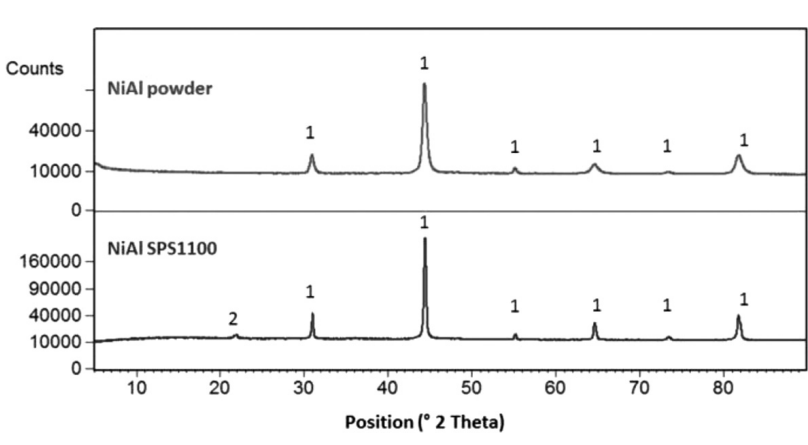

Figure 3: XRD pattern of NiAl powder and compacted material $(1=\mathrm{NiAl}, 2$ = graphite $)$

Slika 3: Rentgenogram prahu NiAl in kompaktiranega materiala $(1=\mathrm{NiAl}, 2$ = grafit $)$

The size of the majority (96\%) of the particles is less than $140 \mu \mathrm{m}$. The phase composition of the powder is given in Figure 3. Peaks of residual aluminium are also visible in the milled powder. Although the powder was leached with a $20 \% \mathrm{NaOH}$ solution, areas of residual $\mathrm{Al}$ are still shown in Figure 1.

Subsequently, the powder was compacted with the SPS method at $1100{ }^{\circ} \mathrm{C}$ for $5 \mathrm{~min}$. The structure of the SPS-prepared material is given in Figure 4. The particles of the initial powder are clearly distinguishable. The dark parts in the structure are pores. The porosity of the SPS-prepared material is $1.9 \pm 0.9 \%$, which is satisfactory for the material prepared by powder-metallurgy processing.

The grains of the compacted material are formed by the particles of the initial powder and no grain coarsening is observed. It can be supposed that the grain size of the compacted material depends only on the particle size of the initial powder. The plot in Figure 5 shows the particle-size distribution of the initial NiAl powder and the grain-size distribution of the SPS-compacted material. It seems that the powder contains more particles with a size of up to $20 \mu \mathrm{m}$. This slight disagreement can be caused by a measurement error. Small particles located

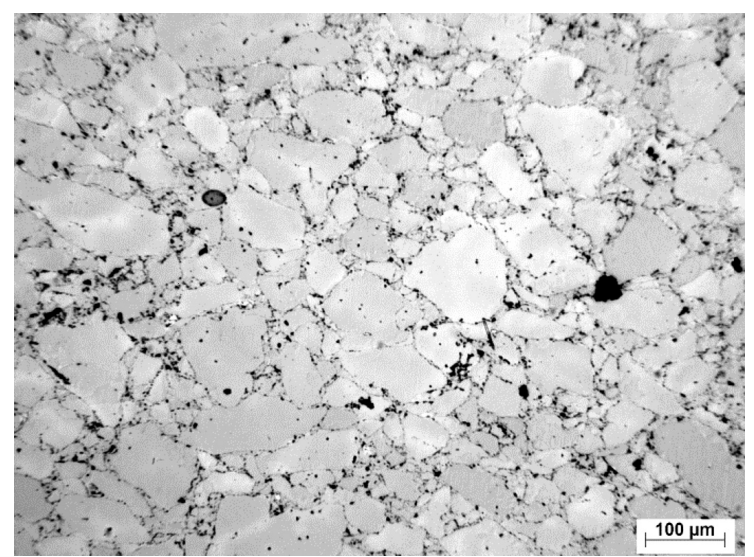

Figure 4: Structure of NiAl material compacted from powder with SPS method $\left(1100{ }^{\circ} \mathrm{C} / 5 \mathrm{~min}\right)(\mathrm{LM})$

Slika 4: Struktura NiAl materiala, kompaktiranega iz prahu po SPS metodi $\left(1100{ }^{\circ} \mathrm{C} / 5 \mathrm{~min}\right)(\mathrm{LM})$

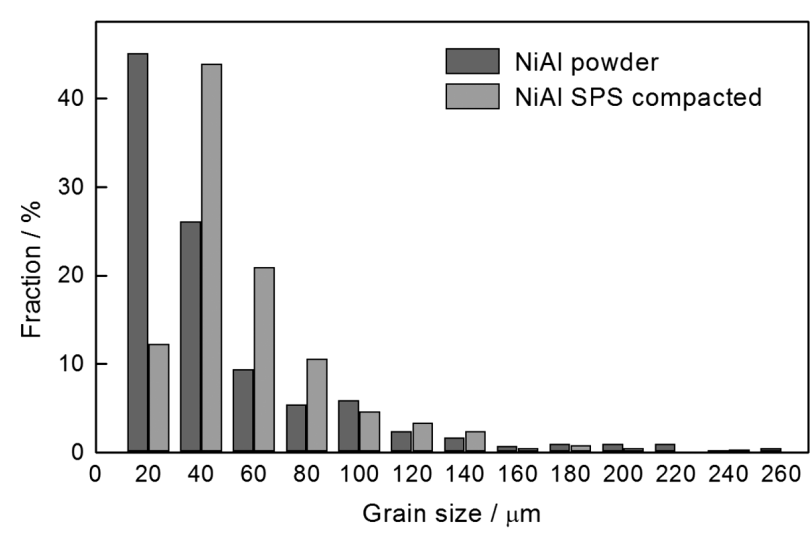

Figure 5: Grain (particle) size distribution of $\mathrm{NiAl}$ powder and compacted material

Slika 5: Razporeditev velikosti delcev prahu NiAl in kompaktiranega materiala

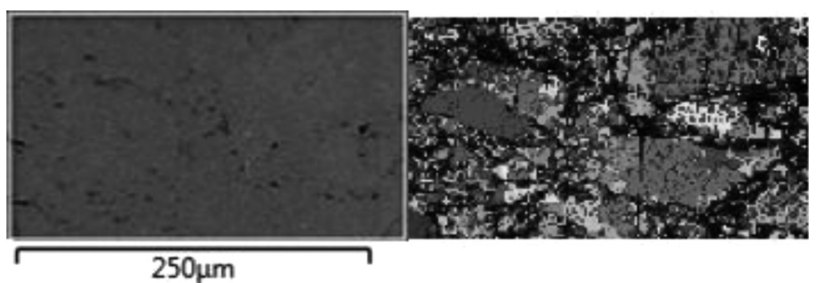

Figure 6: SEM micrograph of NiAl material compacted from powder with SPS method $\left(1100{ }^{\circ} \mathrm{C} / 5 \mathrm{~min}\right)$ and EBSD scan of the area

Slika 6: SEM-posnetek NiAl materiala, kompaktiranega iz prahu po SPS metodi $\left(1100{ }^{\circ} \mathrm{C} / 5 \mathrm{~min}\right)$ in EBSD posnetek področja

at the grain boundaries cannot be distinguished as easily as the separate particles in the mounting material.

The EBSD analysis (Figure 6) of the SPS-compacted material proved that the area of the initial-powder particles is monocrystalline. Between the large, clearly seen particles (grains of the compacted material), there are areas where the crystallographic orientation is not very clear. These areas at the grain boundaries can exhibit a large misorientation or can be oxidised.

The amount of residual $\mathrm{Al}$ is lower than a 2-5\% of mass fraction because it is not detectable with XRD, as shown in Figure 3. The same is true of the oxide content in the initial powder and also in the SPS-compacted

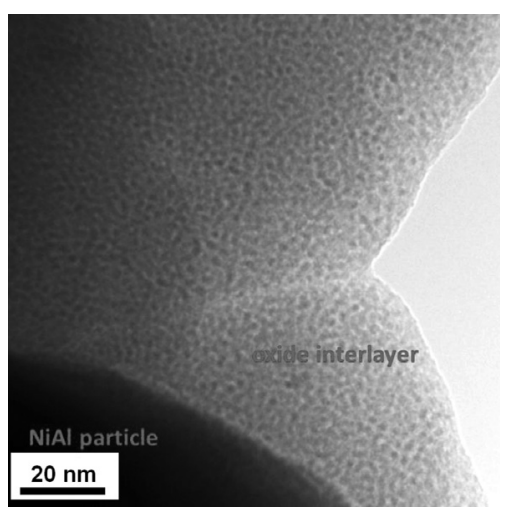

Figure 7: TEM micrograph of NiAl material compacted from powder with SPS method $\left(1100^{\circ} \mathrm{C} / 5 \mathrm{~min}\right)$

Slika 7: TEM-posnetek NiAl kompaktiranega materiala iz prahu po metodi SPS $\left(1100{ }^{\circ} \mathrm{C} / 5 \mathrm{~min}\right)$ 


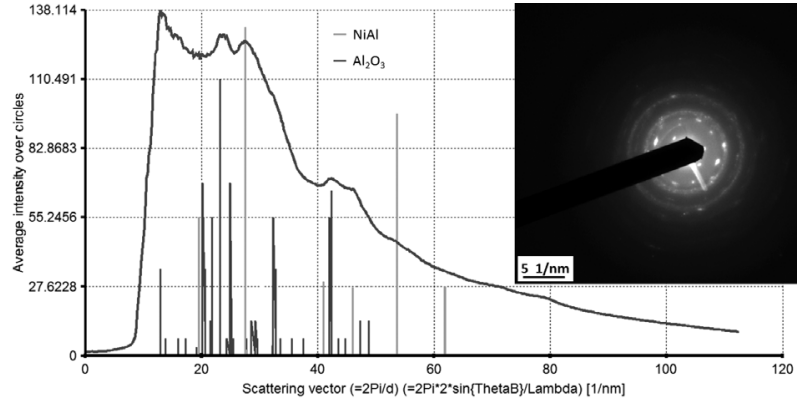

Figure 8: SAED pattern of the grain boundary and diffraction pattern obtained by integrating it in Process Diffraction software. The grain boundary is composed of $\mathrm{NiAl}$ and $\mathrm{Al}_{2} \mathrm{O}_{3}$ phases.

Slika 8: SAED-posnetek meje zrna in posnetek uklona, dobljen z vstavitvijo v programsko opremo Difrakcija procesa. Meja zrna je sestavljena iz faz NiAl in $\mathrm{Al}_{2} \mathrm{O}_{3}$.

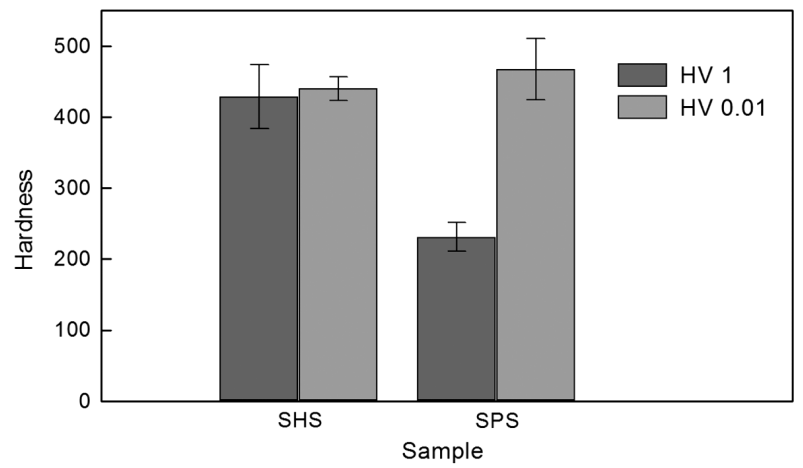

Figure 9: Microhardness and macrohardness of samples after SHS preparation and powder-metallurgicy preparation with SPS

Slika 9: Mikrotrdota in trdota vzorcev po SHS pripravi in po metalurški obdelavi z SPS metodo

product. The only excess peak in the XRD pattern of the SPS-compacted material relates to the graphite from the protection graphite foil used in the SPS process.

A detailed material observation made using TEM is given in Figure 7 and it shows the structure of a grain boundary. In the left bottom part, a dark $\mathrm{NiAl}$ particle is located. It can be seen that the particles are connected by a nanocrystalline oxide interlayer. The amount, thickness and crystallinity of the oxide layer are not sufficient to be detected with XRD or EBSD analysis, but they can be distinguished with selected area electron diffraction (SAED), as shown in Figure 8.

The fact that the weak parts of the material are the grain boundaries is also proved with the hardness measurement. While the microhardness (inside individual particles) is the same for the SHS material and for the SPS-compacted material, the macrohardness (measured with a load of $1 \mathrm{~kg}$ ) varies significantly (Figure 9). These results indicate that micro-properties stay the same after a consolidation, while macro-properties change significantly due to the formation of an oxide interlayer during a compaction. The question is what would happen if the SHS process was performed in an inert atmosphere.

\section{CONCLUSION}

The powder-metallurgy preparation of NiAl consisting of the SHS NiAl preparation, the milling and the SPS compaction is a promising method for obtaining bulk intermetallic materials. The grain size of an SPS-compacted material is mainly determined by the grain-size distribution of the initial powder. The grain size was estimated to be less than $40 \mu \mathrm{m}$. It was proved that the particles of the initial powder are interconnected by a thin oxide layer, which decreases the macroscopic and also microscopic properties of the material.

\section{Acknowledgement}

This research was financially supported by the Czech Science Foundation, project No. P108/12/G043.

\section{REFERENCES}

${ }^{1}$ D. Tingaud, L. Stuppfler, S. Paris, D. Vrel, F. Bernard, C. Penot, F. Nardou, Time-Resolved X-ray Diffraction Study of SHS-produced $\mathrm{NiAl}$ and NiAl-ZrO2 Composites, International Journal of SelfPropagating High-Temperature Synthesis, 16 (2007) 1, 12-17, doi:10.3103/S1061386207010025

${ }^{2}$ P. Novák, D. Šotka, M. Novák, A. Michalcová, J. Šerák, D. Vojtěch, Production of NiAl-matrix composites by reactive sintering, Powder Metallurgy, 54 (2011) 3, 308-313, doi:10.1179/003258909X 12518163

${ }^{3}$ J. Guo, Z. Wang, L. Sheng, L. Zhou, C. Youya, Z. Chen, L. Song, Wear properties of NiAl based materials, Progress in Natural Science: Materials International, 22 (2012) 5, 414-425, doi:10.1016/ j.pnsc. 2012.10 .008

${ }^{4}$ O. Ozdemir, S. Zeytin, C. Bindal, A study on NiAl produced by pressure-assisted combustion synthesis, Vacuum, 84 (2010), 430-437, doi:10.1016/j.vacuum.2009.09.006

${ }^{5}$ A. Biswas, S. K. Roy, Comparison between the microstructural evolutions of two modes of SHS of NiAl: key to a common reaction mechanism, Acta Materialia, 52 (2004), 257-270, doi:10.1016/ j.actamat.2003.08.018

${ }^{6}$ M. Tokita, Spark Plasma Sintering (SPS) Method, Systems, and Applications, Handbook of Advanced Ceramics, (2013), 1149-1177, doi:10.1016/B978-0-12-385469-8.00060-5

${ }^{7}$ Z. A. Munir, U. Anselmi-Tamburini, M. Ohyanagi, The effect of electric field and pressure on the synthesis and consolidation of materials: A review of the spark plasma sintering method, Journal of Materials Science, 41 (2006) 3, 763-777, doi:10.1007/s10853006-6555-2

${ }^{8}$ D. M. Hulbert, D. Jiang, D. V. Dudina, A. K. Mukherjee, The synthesis and consolidation of hard materials by spark plasma sintering, International Journal of Refractory Metals and Hard Materials, 27 (2009), 367-375, doi:10.1016/j.ijrmhm.2008.09.011

${ }^{9}$ L. Wang, J. Zhang, J. Wan, Recent development in reactive synthesis of nanostructured bulk materials by spark plasma sintering, International Journal of Refractory Metals and Hard Materials, 39 (2013), 103-112, doi:10.1016/j.ijrmhm.2013.01.017

${ }^{10}$ G. F. Taylor, Apparatus for making hard metal compositions, US Patent $1,896,854,1993$

${ }^{11}$ K. Inoue, Electric discharge sintering, US Patent 3, 241, 956, 1966

${ }^{12} \mathrm{M}$. Tokita, Trends in advanced SPS spark plasma sintering systems and technology, Journal of the Society of Powder Technology, 30 (1993) 11, 790-804, doi:10.4164/sptj.30.11_790 